Original Research Paper

\title{
Efektivitas Program Penyuluhan Perikanan Sebagai Upaya Peningkatan Kemampuan Pembudidayaan Ikan Air Tawar di Desa Pringgabaya
}

\author{
Muh. Zubair ${ }^{1}$, Anis Faozia ${ }^{2 *}$, Khairil Anwar ${ }^{3}$, M. Dony Islahul Hayyi ${ }^{4}$, Muhammad Yunani ${ }^{5}$, Nabila Reza \\ Kharista $^{6}$

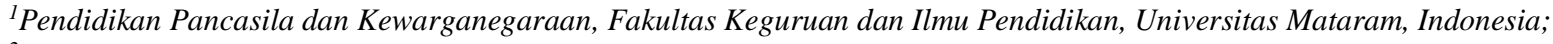 \\ ${ }^{2}$ Hubungan Internasonal, Fakultas Ilmu Sosial dan Ilmu Politik, Universitas Mataram, Indonesia; \\ ${ }^{3}$ Teknik Mesin, Fakultas Teknik, Universitas Mataram, Mataram, Indonesia; \\ ${ }^{4}$ Managemen, Fakultas Ekonomi dan Bisnis Universitas Mataram, Mataram, Indonesia; \\ ${ }^{5}$ Ilmu Komunikasi, Fakultas Ilmu Sosial dan Ilmu Politik, Universitas Mataram, Indonesia; \\ ${ }^{6}$ Akuntansi, Fakultas Ekonomi dan Bisnis, Universitas Mataram, Mataram, Indonesia.
}

https://doi.org/10.29303/jpmpi.v3i2.904

Sitasi: Zubair, M., Faozia, A., Anwar. K., Hayyi, M. D. I., Yunani, M., \& Kharista, N. R. (2021). Efektivitas Program Penyuluhan Perikanan Sebagai Upaya Peningkatan Kemampuan Pembudidayaan Ikan Air Tawar di Desa Pringgabaya. Jurnal Pengabdian Magister Pendidikan IPA, 4(3)

\section{Article history}

Received: 19 Juli 2021

Revised: 31 Juli 2020

Accepted: 19 Agustus 2021

*Corresponding Author: Anis Faozia, Hubungan Internasonal, Fakultas Ilmu Sosial dan Ilmu Politik, Universitas Mataram, Indonesia;

Email : aaniszia@gmail.com

\begin{abstract}
Penelitian ini bertujuan untuk mengetahui tingkat efektivitas program penyuluhan perikanan yang dilakukan oleh mahasiswa KKN Universitas Mataram terhadap peningkatan kemampuan pembudidayaan ikan air tawar di Desa Pringgabaya. Desa Pringgabaya memiliki potensi pengembangan pembudidaya ikan air tawar dengan tersedianya lokasi kolam dan sumber air yang tak pernah kering sepanjang tahun. Namun dalam pemanfaatan dan pengoptimalan potensi tersebut tidak dapat dimaksimalkan dikarenakan pengetahuan masyarakat akan pembudidayaan ikan konsumsi yang tepat belum menyeluruh. Data yang digunakan dalam penelitian ini adalah data primer dan data sekunder. Data primer diperoleh dari hasil observasi lapangan dan wawancara, sedangkan dapat sekunder didapatkan dari kajian pustaka, web internet dan jurnal online. Metode penelitian yang dilakukan ialah kualitatif deskriptif. Metode ini dipilih agar penulis mampu menjelaskan dan menggambarkan keadaan langsung yang terjadi di lapangan. Hasil dari penelitian ini adalah kemampuan masyarakat khususnya mitra yang digandeng dalam penelitian meningkat dari 10 indikator yang diberikan. Dari 10 indikator ketercapaian, terdapat 9 indikator yang tercapai sehingga dapat ditarik kesimpulan bahwa tingkat keefektifannya mencapai 90\%. Program ini terbukti mampu meningkatkan kemampuan masyarakat Desa Pringgabaya dalam pembudidayaan ikan air tawar.
\end{abstract}

Keywords: Penyuluhan; Ikan Air Tawar; Pembudidayaan; Efektifitas.

\section{Pendahuluan}

Perikanan air tawar merupakan salah satu sektor yang dikembangkan di Indonesia. Terdapat beberapa jenis ikan yang aktif dibudidayakan di Indonesia seperti ikan nila, mas, gurame, bandeng, lele dan jenis ikan lainnya. Salah satu ikan yang terkenal dan tingkat konsumsinya atau peminatnya tinggi ialah ikan nila. Dari data yang diperoleh dari statistic Kelautan dan Perikanan pada hasil produksi tahun 2020 ditemukan bahwa produksi ikan nila di beberapa provinsi Indonesia mencapai 364.747,10 ton. Provinsi Nusa Tenggara barat sendiri turut hadir dan menyumbang angka yang tinggi untuk produksi ikan nila sebanyak 39,790,42 ton. Tepatnya berada pada urutan ke-3 setelah jawa tengah dan jawa timur. Tingginya tingkat produksi 
ikan di NTB dikarenakan banyaknya tersedia kolam pembudidayaan serta sumber air yang masih baik untuk sanitasi ikan dalam berkembang. Salah satu kecamatan yang turut menyumbang angka produksi ini ialah Kecamatan Pringgabaya, Desa Pringgabaya.

Desa Pringgabaya memiliki 20 kekadusan dengan beberapa kekadusan memiliki sumber mata air yang dimanfaatkan oleh warga sekitar untuk membuat kolam dan membudidayakan ikan. Dari beberapa dusun tersebut, dusun yang aktif ialah Dusun Karang Kapitan dan Dusun Ketapang. Namun dalam pengembangan pembudidayaanya terdapat faktor-faktor yang menghambatnya. Beberapa faktor yang ditemukan dilapangan yaitu keterbatasan modal untuk pengembangan dan pembudidayaan ikan, kurangnya pengetahuan untuk pembudidayaan ikan yang baik dan tepat untuk konsumsi serta kurangnya kesadaran masyarakat atas potensi dari pengembangan pembudidayaan ikan nila yang mampu menghasilkan pendapatan untuk masyarakat. Faktor-faktor ini dapat terjadi dikarenakan tidak adanya program yang mengarahkan masyarakat untuk mengedukasi masyarakat.

\section{Metode}

1) Waktu dan Tempat

Program ini dilaksanakan di Dusun

Karang Kapitan, Desa Pringgabaya, Kecamatan Pringgabaya, Kabupaten Lombok Timur, Nusa Tenggara Barat pada bulan JuniJuli 2021.

2) Alat dan Bahan

Alat yang dibutuhkan dalam program ini adalah skop, mesin penguras air, ember, kursi, microphone, LCD. Sedangkan bahan yang dibutuhkan dalam program ini berupa ikan dan pakan ikan.

3) Bentuk Kegiatan

Bentuk kegiatan dalam program penyuluhan perikanan untuk peningkatan kemampuan pembudidayaan ikan air tawar ialah sosialisasi dan pemantauan kolam budidaya ikan air tawar yang ada di Dusun Karang Kapitan. Kegiatan-kegiatan tersebut terdiri dari rangkaian pensurveian kolam budidaya, pengerukan kolam agar sesuai dengan kedalaman kolam budidaya, persiapan kolam dengan pemberian kapur dan pupuk organik, pelepasan bibit ikan hingga pemberian pakan ikan dan pembudidayaan.

4) Metode

Program ini menggunakan metode deskriptif kualitatif. Bogdan dan Tailor seperti yang dikutip oleh Moeleong, mendefinisikan metodologi kualitatif sebagai prosedur penelitian yang menghasilkan data deskriptif berupa kata-kata tertulis atau lisan atau dari bentuk tindakan kebijakan (Moeleong, Lexy J. 2002:112). Sedangkan menurut I Made Winartha (2006,155), metode analisis deskriptif kualitatif adalah menganalisis, menggambarkan dan meringkas berbagai kondisi, situasi dari berbagai data yang dikumpulkan berupa hasil wawancara atau pengamatan mengenai masalah yang diteliti yang terjadi di lapangan. Jenis data yang digunakan adalah primer dan sekunder dengan teknik pengambilan data melalui observasi lapangan, wawancara dan studi pustaka. Kesemuaan data tersebut diolah dan dianalisis sedemikian rupa sehingga dapat ditarik kesimpulan pada akhirnya.

\section{Hasil dan Pembahasan}

Dusun Karang Kapitan merupakan satu dari sekian Dusun yang Desa Pringgabaya yang memiliki mata air dan kolam pembudidayaan ikan. Mata air yang berada di dusun ini tidak pernah kering sepanjang tahun sehingga masyarakat sekitar memanfaatkannya dengan membuat kolam pemandian umum untuk warga dan kolam budidaya ikan. Air yang jernih dan tetap ada membuat kualitas kolam pembudidayaan ikan menjadi ideal untuk dimanfaatkan. Namun keterbatasan modal dan pengetahuan akan pembudidayaan ikan yang baik dan benar membuat warga sekitar khususnya mitra yang mengelola kolam tersebut yaitu komunitas remaja "PADA RATA" tidak bisa mengefektifkan potensi yang dimiliki.

Melihat potensi dari ketersediaan lokasi dan pengelola tetap dari kolam di Dusun Karang Kapitan, Desa Pringgabaya, KKN Universitas Mataram mencoba untuk memanfaatkan dan mengoptimalkan potensi tersebut. Bentuk kegiatan yang dilakukan dalam Kegiatan Kuliah Kerja Nyata (KKN) yaitu memfokuskan pemberian edukasi mengenai pembudidayaan ikan air tawar 
yang baik dan benar. Pemberian edukasi dilakukan dengan program penyuluhan perikanan oleh Instalasi Industri Kelautan dan Perikanan dengan meminta seorang penyuluh yang ahli dalam bidang perikanan air tawar khususnya jenis ikan nila. Terdapat beberapa rangkaian kegiatan yang merangkai program penyuluhan ini antara lain:

\section{1) Pensurveian Lokasi Kolam}

Pensurveian dilaksanakan selama 2 kali sepanjang periode KKN. Survei pertama dilakukan untuk mengetahui lokasi kolam dan mengumpulkan beberapa informasi serta membangun relasi pada mitra pengelola kolam pembudidayaan yaitu komunitas remaja "PADA RATA". Survei kedua dilakukan untuk mengukur kolam pada bagian panjang, lebar, kedalaman air, kedalaman kolam, outlet (jalur keluarnya air) kolam, serta melakukan dokumentasi guna penyusunan proposal yang akan dikirim kepada Dinas IIKP.

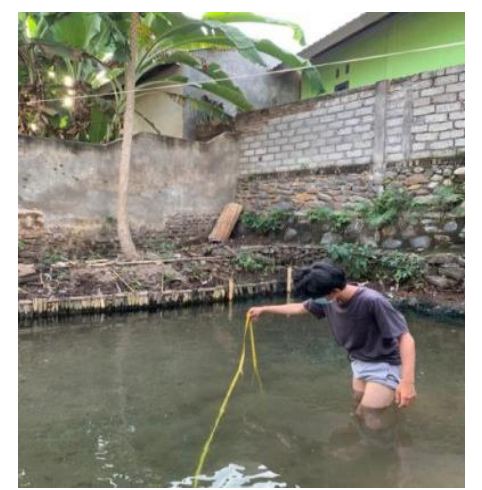

Gambar 1. Mengukur kedalaman kolam

Hasil pensurveian ditemukan bahwa terdapat 2 kolam yang akan digunakan untuk pembudidayaan ikan air tawar dengan jenis ikan nila yaitu kolam A dan Kolam B. kolam A dengan ukuran panjang x lebar yaitu 11 x 6 m sedangkan kolam B yaitu $6 \times 4 \mathrm{~m}$. Kedalaman kolam A yaitu $30-$ $50 \mathrm{~cm}$ sedangkan kolam B sebesar $15-30 \mathrm{~cm}$ dalamnya. Kedalaman kolam yang tidak merata diakibatkan dari erosi tanah yang terjadi ada pinggiran kolam. Adapun data lain yang ditemukan yaitu jarak permukaan air terhadap bibir kolam sebesar $17 \mathrm{~cm}$. Ketebalan pinggiran kolam sebesar $30 \mathrm{~cm}$.
2) Pengerukan kolam tempat pembudidayaan ikan

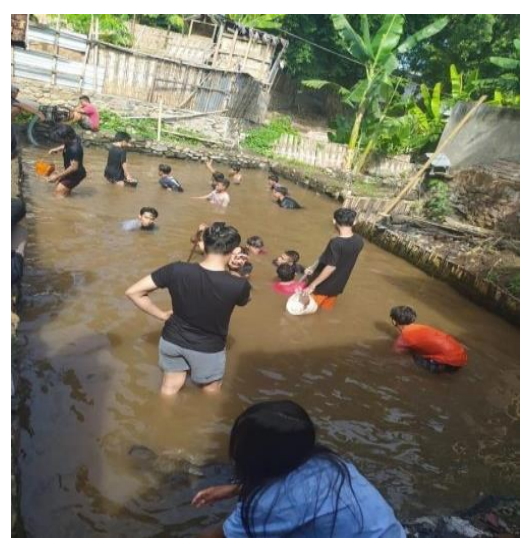

Gambar 2. Pengerukan kolam

Pengerukan kolam diawali dengan proses pengurasan air kolam menggunakan mesin penyalur air, hal ini dikarenakan outlet atau saluran pembuangan air tidak mampu mengeringkan kolam dan sumber air dari mata air tidak dapat dibendung atau dialihkan alirannya. Pengurasan air kolam ini nantinya akan memudahkan proses pengerukan dasar kolam. Pengerukan kolam dilakukan sebanyak 2 kali dimana kedalaman pada pengerukan pertama belum memenuhi standar kolam yang ideal digunakan untuk pembudidayaan ikan. Standar kolam pembudidayaan untuk ikan air tawar yang disarankan oleh IIKP yaitu 70-120 cm. Ukuran kedalaman $80 \mathrm{~cm}$ didapatkan setelah 2 kali pengerukan. Adapun alat yang digunakan untuk pengerukan yaitu cangkul, sekop, dan ember. Pengerukan dilakukan oleh mahasiswa KKN beserta komunitas remaja PADARATA pada pagi dan sore hari.

3) Penyuluhan pembudidayaan ikan air tawar oleh IIKP

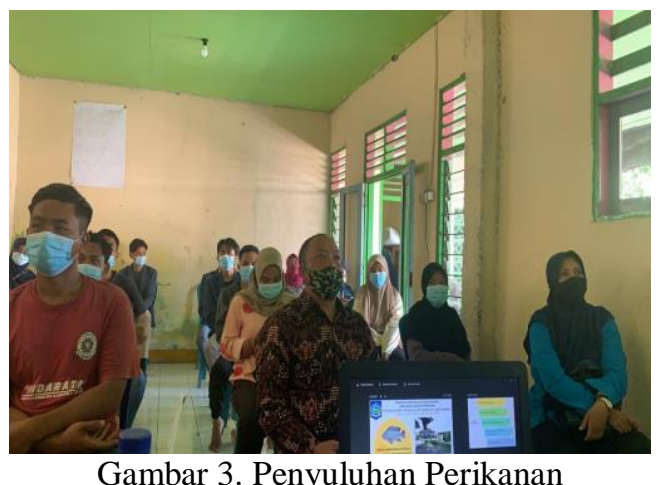

Penyuluhan dilakukan di Rumah Kepala Dusun Karang Kapitan dengan Pemateri dari 
penyuluh IIKP. Materi disampaikan melalui media power point dan sosialisasi tentang berbagai macam seluk-beluk pembudidayaan ikan. Materi yang disampaikan mulai dari pengaturan kolam ikan yang baik, jenis ikan yang dibudidayakan, cara pembesaran ikan, penyakit pada ikan serta tahapantahapan pembudidayaan serta terjadi diskusi Tanya jawab mengenai permasalahan yang ditemukan oleh pengelola dengan penyuluh.

Setelah kegiatan penyuluhan dilakukan, tim penyuluh dari IIKP beserta dengan pengelola kolam menuju ke kolam lokasi pembudidayaan ikan untuk peninjauan lanjutan. Setelah sampai ke kolam, dilakukan diskusi dan pengarahan oleh pihak IIKP terdapat 2 kolam target seperti kedalamaan kolam yang harus disesuaikan hingga pembuatan outlet agar arus air lebih deras. Arus air yang lebih deras disinyalir dapat menambah oksigen dalam air untuk mendukung daya hidup ikan. Dari tinjauan yang dilakukan, kapasitas ikan yang dapat ditebar atau dibudidayakan hingga panen dengan ukuran luas kolam A ialah 1650 benih. Sedangkan kolam B memiliki kapasitas yang lebih minim dan lebih disarankan untuk membudidayakan ikan hias karena kedalaman kolam B yang relative tidak ideal untuk pembudidayan ikan konsumsi.

4) Pemberian kapur dan pupuk organik pada kolam

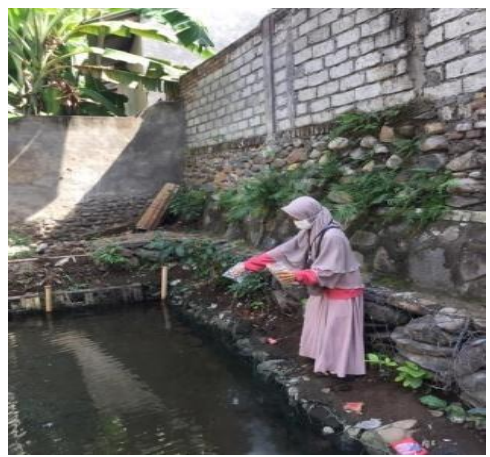

Gambar 4. Pengapuran

Pemberian kapur dimaksudkan dalam proses ini untuk menghilangkan hama penyakit yang berada dalam genangan air kolam yang biasanya menyerang ikan. Teknik pengapuran kolam dilakukan dengan menaburkan kapur pada kolam dan merendamnya selama 3 hari. Kapur yang digunakan ialah kapur untuk pertanian atau kapur untuk bangunan,namun pada penerapan kapur bangunan volumenya lebih sedikit. Sedangkan pemberian pupuk organik dimaksudkan untuk menghidupkan zooplankton yang ada di kolam yang akan menjadi makanan alami ikan. Pemberian pupuk organik yang paling bagus berasal dari pupuk kotoran kambing, sapi ataupun kotoran ayam. Setelah proses penaburan pupuk organik pada kolam, dilakukan perendaman selama 1 hari atau 24 jam full. Setelah 24 jam, air kolam harus dikuras agar mengurangi amoniak yang berada pada air. Selanjutnya, kolam diisi dengan air kembali.

5) Pelepasan bibit ikan nila pada kolam pembudidayaan

Pelepasan bibit ikan yang akan dibudidayakan ialah ikan nila anjani yang dibenihkan oleh Dinas IIKP di Aikmel. Ukuran nila yang ditebar pada kolam yaitu $3-5 \mathrm{~cm}$ dengan jumlah 1000 benih. Sebelum dilakukan pelepasan, ikan terlebih dahulu diapungkan dalam kolam dengan wadah berisi air dan oksigen (wadah pembungkus saat bibit dibawa) selama 15 menit agar ikan beradaptasi dengan suhu kolam. Setelah itu, teknik pelepasannya dengan langsung membuka kemasan diatas permukaan air agar ikan langsung memasuk pada air dalam kolam. Hal ini dilakukan agar mengurangi potensi ikan yang mati saat penuangan ke kolam dari kemasan.

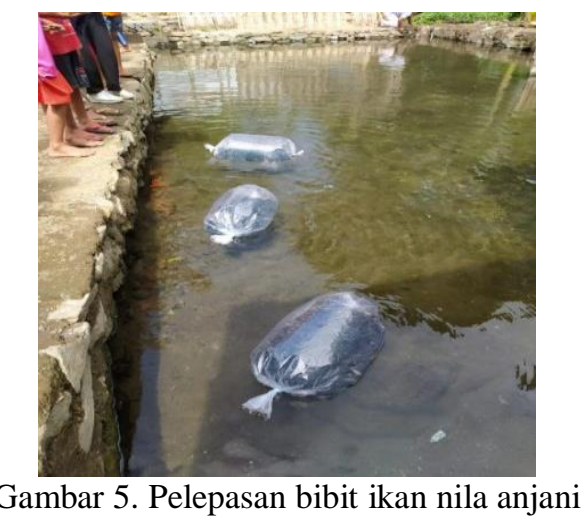

6) Pemberian pakan pada ikan nila

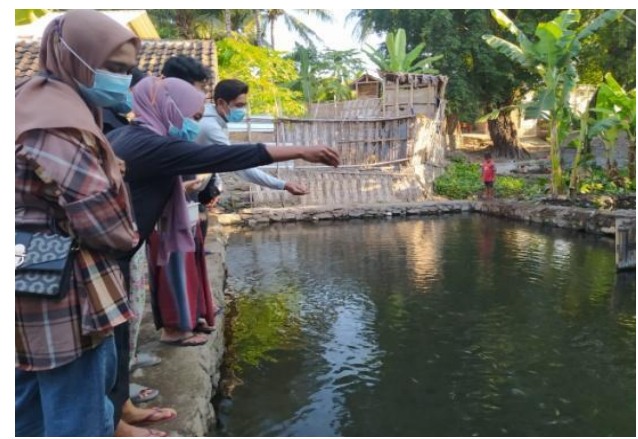

Gambar 6. Pemberian pakan ikan 
Pemberian pakan pada ikan nila dilakukan selama 2 kali sehari yaitu pada pagi dan sore hari. Jumlah pakan yang diberikan yaitu $1 / 2 \mathrm{~kg}$ dengan jenis pakan ikan terapung dengan kandungan protein $33 \%$. Kandungan protein yang ideal untuk ikan budidaya yang nantinya akan dikonsumsi ialah diatas $30 \%$. Ukuran pakan juga harus disesuaikan dengan ukuran ikan yang akan diberikan makan, ukuran pakan yang digunakan masuk pada kategori M2 atau pakan yang relative butirannya kecil. Pakan tidak langsung diberikan namun dilakukan perendaman sekitar 5-10 menit agar lebih lunak dan dapat dimakan oleh ikan. Teknik perendaman dengan memercikan air agar pakan melunak namun tidak merubah bentuk pakan tersebut. teknik ini juga digunakan agar pakan tidak mengembang pada tubuh ikan dan membuat perut ikan membesar yang akan berimbas pada ikan mati karena saluran pencernaan yang penuh. Pemberian pakan juga tidak sekaligus diberikan, namun diberikan secara berangsur-angsur agar pakan tidak mengotori kolam dengan minyak yang dikandung dan pakan tidak terbuang karena tidak termakan oleh ikan.

7) Pemantauan perkembangan ikan nila

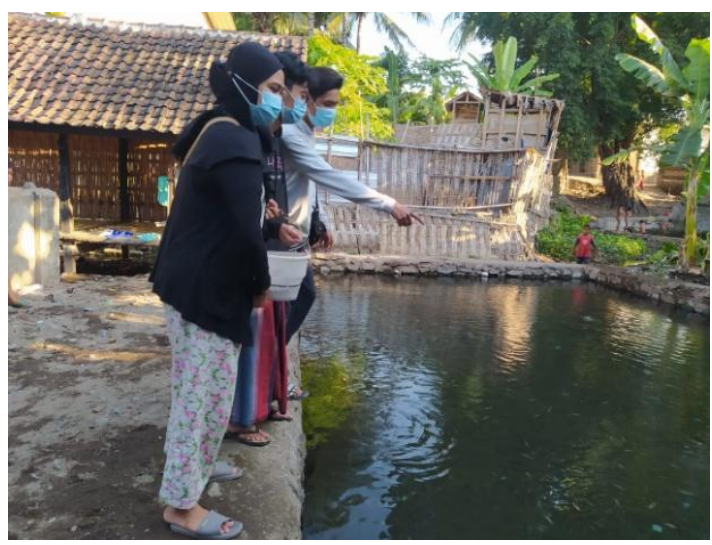

Gambar 7. Pemantauan perkembangan ikan nila
Pemantauan dilakukan selama 2 kali dalam sehari bersamaan dengan pemberian pakan. Terdapat beberapa hal yang harus diperhatikan yaitu saluran air yang keluar haruslah lancar, jumlah ikan yang mati setiap hari, ikan yang terkena penyakit dan antusias ikan dalam makan. Dari pemantauan yang dilakukan, saluran air tetap lancar sehingga oksigen ikan tetap terjaga. Ikan yang mati pasca pelepasan tidak ada, hal ini menginformasikan bahwa teknik pelepasan dan keadaan kolam sudah tepat untuk lingkungan ikan hidup. Terdapat beberapa ikan yang terkena penyakit jamuran, hal ini dikarenakan terdapat ikan yang telah berada di kolam yang membawa bakteri tersebut dan menularkannya kepada ikan yang lainnya. Langkah yang bisa dilakukan ialah menempatkan ikan yang terkena penyakit pada kolam yang terpisah dan memberikan obat pada air kolam. Dari hasil pemantauan juga ditemukan bahwa antusias ikan saat proses pemberian pakan sangat tinggi, hal ini menunjukan bahwa ikan sehat dan terus bertumbuh kedepannya.

Selama proses dalam program penyuluhan perikanan terus terjadi koordinasi dari mahasiswa KKN-Komunitas PADA RATA serta dinas IIKP. Pengawalan ini terus dilakukan agar tidak ada langkah yang salah atau terlewati dari proses pembudidayaan ikan air tawar yang tepat. Respon pengelola terhadap penyuluhan yang diberikan serta rangkaian proses lainnya sangatlah positif. Dari hasil wawancara yang dilakukan tingkat pengetahuan untuk pembudidayaan ikan meningkat sangat pesat. Awalnya pengelola tidak memiliki pengetahuan sama sekali mengenai pembudidayaan ikan air tawar untuk kebutuhan konsumsi yang tepat. Setelah proses penyuluhan dan pembimbingan berikut peningkatan yang terjadi pada indikator-indikator yang telah disediakan. Indikator-indikator ini didapatkan dari hasil penyuluhan yang dilakukan dan hasil pengamatan di lapangan.

Tabel 1. Tingkat Efektifitas Program yang Penyuluhan Terhadap Kemampuan Pembudidayaan Ikan Air Tawar pada Mitra yang Disasar.

\begin{tabular}{|c|c|c|c|c|c|}
\hline \multirow{2}{*}{ No } & \multirow{2}{*}{ Indikator } & \multicolumn{4}{|c|}{ Ketercapaian } \\
\cline { 3 - 5 } & & \multicolumn{2}{|c|}{ Sebelum penyuluhan } & \multicolumn{2}{c|}{ Sesudah penyuluhan } \\
\cline { 3 - 5 } & $\begin{array}{c}\text { Tidak } \\
\text { mengetahui }\end{array}$ & mengetahui & $\begin{array}{c}\text { Tidak } \\
\text { mengetahui }\end{array}$ & mengetahui \\
\hline 1 & $\begin{array}{l}\text { Kolam ideal untuk pembudidayaan ikan } \\
\text { kedalamannya berkisar 70-120 cm. }\end{array}$ & $\sqrt{ }$ & & $\sqrt{ }$ \\
\hline
\end{tabular}




\begin{tabular}{|c|c|c|c|c|}
\hline 2 & $\begin{array}{l}\text { Kolam harus memiliki inlet dan outlet } \\
\text { yang baik }\end{array}$ & & $\sqrt{ }$ & $\sqrt{ }$ \\
\hline 3 & $\begin{array}{l}\text { Terdapat perbedaan jenis pakan sesuai } \\
\text { umur ikan }\end{array}$ & $\sqrt{ }$ & & $\sqrt{ }$ \\
\hline 4 & Pemberian pakan pada ikan 2 kali sehari & $\sqrt{ }$ & & $\sqrt{ }$ \\
\hline 5 & $\begin{array}{l}\text { Pada proses persiapan pengisian kolam } \\
\text { diperlukan pengapuran dan pemupukan }\end{array}$ & $\sqrt{ }$ & & $\sqrt{ }$ \\
\hline 6 & Terdapat hama pada ikan dan kolam & $\sqrt{ }$ & & $\sqrt{ }$ \\
\hline 7 & $\begin{array}{l}\text { Pakan yang baik yaitu pakan yang } \\
\text { memiliki kandungan protein diatas } 30 \%\end{array}$ & $\sqrt{ }$ & & $\sqrt{ }$ \\
\hline 8 & $\begin{array}{l}\text { Kualitas air berpengaruh terhadap } \\
\text { pertumbuhan. }\end{array}$ & $\sqrt{ }$ & & $\sqrt{ }$ \\
\hline 9 & $\begin{array}{l}\text { Penyakit ikan dapat diobati dengan } \\
\text { beberapa metode dan obat yang sesuai. }\end{array}$ & $\sqrt{ }$ & & $\sqrt{ }$ \\
\hline 10 & $\begin{array}{l}\text { Waktu panen ikan yang baik adalah pagi } \\
\text { atau sore hari dengan beberapa orang } \\
\text { saja dalam prosesnya. }\end{array}$ & $\sqrt{ }$ & & $\sqrt{ }$ \\
\hline
\end{tabular}

Penjabaran tabel diatas dengan beberapa indikator mampu menunjukan tingkat efektifitas program yang penyuluhan terhadap kemampuan pembudidayaan ikan air tawar pada mitra yang disasar. Dari 10 indikator terdapat 9 indikator kemajuan yang mampu tercapai dan diketahui oleh komunitas remaja PADA RATA dalam pembudidayaan ikan air tawar. Tingkat keberhasilan program penyuluhan terhadap kemampuan pembudidayaan ikan apabila diukur melalui 10 indikator yang telah dipilih ialah $90 \%$. Sehingga program penyuluhan perikanan ini terbukti efektif dalam meningkatkan kemampuan pembudidayaan ikan air tawar di Dusun Karang Kapitan, Desa Pringgabaya.

\section{Kesimpulan}

Ketidaktahuan masyarakat Dusun Karang Kapitan akan potensi yang dimiliki disekitar lingkungan tempat tinggal merupakan suatu yang harus dibenahi. Adanya potensi mata air dan kolam yang telah tersedia, sudah seharusnya dimanfaatkan untuk meningkatkan ekonomi masyarakat sekaligus menyediakan sumber protein hewani berupa ikan air tawar. Salah satu pemanfaatan yang dapat dilakukan yaitu dengan melakukan pembudidayaan di kolam tersebut. Pembudidayaan ikan tentunya harus menggunakan ilmu atau pengalaman agar ikan yang didapatkan hasilnya maksimal untuk kebutuhan konsumsi. Kolam yang dikelola oleh komunitas remaja PADA RATA yang terletak di Dusun Karang Kapitan belum memenuhi standar sebagai kolam pembudidayaan. Oleh karena itu, mahasiswa KKN Universitas Mataram bersama dengan pengelola melakukan program penyuluhan perikanan yang diawali dengan pengkondisian kolam dengan dilakukannya pengerukan, pengapuran serta pemupukan. Setelah kolam ideal dengan kedalaman $80 \mathrm{~cm}$, dilakukan pelepasan bibit ikan nila anjani sebanyak 1000 ekor. Pemberian pakan untuk mendukung pertumbuhan bibit ikan pun dilaksanakan sebanyak 2 kali dalam sehari yaitu pagi dan sore hari. Setelah proses tersebut, terus dilakukan pemantauan dan pengkonsultasian dengan Dinas Instalasi Industri Kelautan dan Perikanan. Hasil dari program penyuluhan perikanan tersebut berdampak positif terhadap pengetahuan dan kemampuan pengelola dalam pembudidayaan ikan. Terdapat 10 indikator permasalahan yang dikaji dan ketercaaian atau peningkatan dalam indikator tersebut ada 9 poin. Mengukur dari hal tersebut dapat disimpulkan bahwa tingkat efektivitas program penyuluhan perikanan terhadap kemampuan pembudidayaan ikan air tawar di Dusun Karang Kapitan mencapai 90\% dan dapat dikatakan efektif serta tepat.

\section{Ucapan Terima Kasih}

Terima kasih kami ucapkan kepada Dosen Pembimbing Lapangan yang telah memberikan arahan dan motivasi dalam pelaksanaan KKN Tematik Universitas Mataram di Desa Pringgabaya. Ucapan terima kasih juga kami sampaikan kepada seluruh masyarakat di Desa Pringgabaya yang telah membantu kami menyelsaikan kegiatan ini dengan baik dari awal hingga akhir. 


\section{Daftar Pustaka}

Administrator. (n.d.). produksi perikanan tahun 2020. Retrieved Agustus 11, 2021, from statistik.kkp.go.id:

https://statistik.kkp.go.id/home.php?m=total $\& \mathrm{i}=2$ \#panel-footer

Agustin, V. D. (2021, Juni 13). Teknik Pembesaran Ikan Nila. Lombok Timur, Nusa Tenggara Barat, Indonesia.

Aliyas, S. N. (2016). Pertumbuhan Dan Kelangsungan Hidup Ikan Nila (Oreochromis Sp.) Yang Dipelihara Pada Media Bersalinitas. jurnal Sains dan Teknologi Tadulako, Volume 5 Nomor 1, 1927.

Meidiana Salsabila, H. S. (2018). Teknik Pembesaran Ikan Nila (Oreochromis Niloticus) Di Instalasi Budidaya Air Tawar Pandaan, Jawa Timur. Journal of Aquaculture and Fish Health Vol. 7 No.3, 118-123.

Ramadan, A. (2020, November 19). Jenis Pelet Ikan Nila Protein Tinggi Sesuai Umur. Retrieved Agustus 15, 2021, from berternak dirumah.my.id: https://www.beternak-

dirumah.my.id/2020/11/pelet-ikan-nila-proteintinggi.html

Subandi. (2011). Deskripsi Kualitatif Sebagai Satu Metode Dalam Penelitian Pertunjukan. Harmonia, 176. 